\title{
Rekomendasi Barang Di Toko Elektrik Menggunakan Algoritma Apriori
}

\author{
Arvian Furqon Yudanar ${ }^{1)}$; Sri Hariyati Fitriasih' ${ }^{2)}$; Muhammad Hasbi ${ }^{3)}$ \\ 1) 3) Program Studi Informatika, STMIK Sinar Nusantara \\ ${ }^{2)}$ Program Studi D3 Sistem Informasi, STMIK Sinar Nusantara \\ 1)15500015.arvian@sinus.ac.id; ${ }^{2}$ fitriasih@sinus.ac.id; ${ }^{3}$ mhasbi@sinus.ac.id
}

\begin{abstract}
Each company or organization which is wants to survive needs to determine the right business strategies. Sales data of products made by the company will get a lot of data. So it is very unfortunate if there is not repetition analyzing. Its offered variety products with a wide range of products, and sometimes the brand influence people to buy the product, to know the highest sales products, it needs to know the relationship one product to others, one of them is existing algorithms in mining data algorithms. They are algorithms apriori to be informed, and it can help of this program, products which appear simultaneously knowable. The purpose of the research is to determine the recommendation of goods, so that purchases of goods stock are efficient. Apriori algorithms including the type of association rules in mining data. One step analysis association phase which is gotten the attention from many researchers to produce the efficient algorithms is the analysis of patterns of high frequency (frequent pattern mining). Important or not an association can be identified by the two benchmarks, namely: support and confidence. Support (support value) is the percentage of the combination of these items in the database, while confidence (value certainty) is a strong relationship between the items in the rules of association. Apriori algorithm can be helpful for the development of marketing strategies. From the validity testing result, the data is efficient if the minimum support more than $10 \%$ and the minimum confidence more than $50 \%$. The calculation needs two different minimum support and minimum confidence to know the best result. The problem is how to increase sales, and find out the interest of buyers in the product. And the results are obtained to decide the layout of the products in the shop window as the effort to increase sales in the store.
\end{abstract}

Keywords : Mining Data, Good Recommendations, Apriori, Algorithm

\section{PENDAHULUAN}

Toko Rokok Elektrik merupakan sebuah toko yang menjual segala kebutuhan yang berkaitan dengan Rokok Elektrik atau yang lebih sering disebut dengan Vapor.

Barang-barang yang dijual di toko berupa: Mecha Mod, Elektrical Mod, Pod System, Starter Kit, Squonker Mod, Atomizer, Liquid Freebase, Liquid Salt Nic, Battery, Charger, Catridge, Replacement Coil, Wire, Coil, Cotton, dan Accessoris lainya. Untuk transaksi penjualan hampir semua toko sekarang menggunakan sistem informasi penjualan. Salah satu data yang dihasilkan dari sistem informasi penjualan tersebut adalah transaksi data penjualan produk. Dengan kegiatan penjualan setiap hari maka otomatis data penjualan tersebut makin lama akan semakin bertambah banyak. Jika dibiarkan saja maka data tersebut tidak bermanfaat. Dan juga adanya transaksi setiap hari mengharuskan pemilik toko untuk memenuhi lagi stok barang yang habis di toko, tidak semua barang yang distok akan habis. Jika stok barang tidak menggunakan strategi, maka barang yang distok tidak akan sesuai dengan keinginan konsumen.

Penjualan yang tidak konsisten sangat merugikan bagi pemilik toko, perlu adanya strategi penyusunan produk di toko agar konsumen lebih tertarik untuk membeli produk - produk ditoko.

Solusi dari permasalahan tersebut adalah bagaimana membentuk pola kombinasi itemsets dan membuat aturan dengan teknik association rule. Pengetahuan yang dihasilkan dari data pengolahan data penjualan dengan algoritma apriori yakni berupa pola kombinasi dan aturan asosiasi, yang dapat digunakan oleh pihak toko salah satunya adalah sebagai acuan penyusunan katalog produk.

Tujuan dari penelitian ini ditujukan untuk menentukan rekomendasi barang berdasarkan data transaksi toko yang sudah ada, diproses dengan menggunakan Algoritma Apriori sehingga dapat menentukan rekomendasi barang yang efisien dan memudahkan toko rokok elektrik dalam membeli stock barang untuk kebutuhan toko. 
Dengan melihat dari jurnal Simbolon, 2019 [1] yang mengangkat permasalahan mengenai algoritma apriori dalam mencari kombinasi barang yang terjual sebagai referensi untuk persediaan barang di toko elektronik. Berdasarkan penelitian dari A. -, F. Marisa, and D. Purnomo, 2016 [2] yang meneliti tentang algoritma apriori untuk mencari produk yang laku dipasaran, sehingga memudahkan pedagang baru yang memiliki modal yang terbatas.

Penelitian yang dilakukan oleh $\mathrm{L}$. Kurniawati, A. E. Kusuma, and B. Dewansyah, 2019 [3] dengan menggunakan metode algoritma apriori, memanfaatkan database transaksi guna mencari aturan asosiatif untuk membuat sistem rekomendasi persediaan spare part compressor.

\section{TINJAUAN PUSTAKA \\ 2.1 Data Mining}

Data Mining adalah serangkaian proses untuk menggali nilai tambah berupa informasi yang selama ini tidak diketahui secara manual dari suatu basis data. Informasi yang dihasilkan diperoleh dengan cara mengekstraksi dan mengenali pola yang penting atau menarik data yang terdapat pada basis data. Data mining terutama digunakan untuk mencari pengetahuan yang terdapat dalam basis data yang besar sehingga sering disebut Knowledge Discovery Database (KDD).

Data mining merupakan salah satu dari rangkaian Knowledge Discovery in Database (KDD). KDD berhubungan dengan Teknik integrasi dan penemuan ilmiah, interpretasi dan visualisasi dari pola sejumlah data [4].

\subsection{Algoritma Apriori}

Algoritma apriori adalah algoritma pengambilan data dengan aturan asosiatif (Association Rule) untuk menentukan hubungan asosiatif suatu kombinasi item. Algoritma ini mengontrol berkembangnya kandidat itemset dari hasil frequent itemset dengan support-based pruning untuk menghilangkan itemset yang tidak menarik dengan menetapkan minimum support. Aturan asosiasi atau sering disebut association rule, merupakan salah satu metode yang digunakan untuk menemukan hubungan diantara data atau bagaimana suatu kelompok data mempengaruhi suatu keberadaan data lain. Aturan asosiasi merupakan salah satu metode yang sering digunakan untuk mencari hubungan antara berbagai item. Hubungan algoritma pariori dengan asosiasi adalah dapat menemukan dua atau lebih attribute dan dua atau lebih objek. Algoritma apriori termasuk jenis aturan pada data mining[5].

Rumus Perhitungan Support :

Support $(A)=\frac{\text { Jumlah Transaksi Mengandung A }}{\text { Total Transaksi }} \times 100 \%$ (1)

Rumus Perhitungan Confidence:

confidence $=P(B \mid A)=$

$\frac{\sum \text { Transaksi mengandun A dan B }}{\sum \text { Transaksi mengandung } A} \times 100 \%$

\subsection{Rekomendasi Barang}

Pada algoritma apriori rekomendasi yaitu menemukan aturan asosiasi keterkaitan antar item sehingga diperoleh pola keterkaitan item.

Pada layanan transaksi jual beli terdapat sistem rekomendasi terkait dengan pola pembelian pengguna tersebut pada data sebelumnya, dimana pola pembelian tersebut dapat dijadikan acuan dalam memberikan rekomendasi barang untuk referensi dalam stok barang pada toko dan penataan barang pada rak toko.[6]

\subsection{XAMPP}

XAMPP adalah perangkat lunak bebas, yang mendukung banyak sistem operasi, merupakan kompilasi dari beberapa program. Fungsinya adalah sebagai server yang berdiri sendiri (localhost), yang terdiri atas program Apache HTTP Server, MySQL database, dan penerjemah bahasa yang ditulis dengan bahasa pemrograman PHP dan Perl.[7]

\subsection{PHP Hypertext Preprocessor (PHP)}

PHP adalah bahasa pemrograman yang digunakan secara luas untuk penanganan pembuatan dan pengembangan sebuah web dan bisa digunakan pada HTML. PHP merupakan singkatan dari "PHP : Hypertext Preprocessor", dan merupakan bahasa yang disertakan dalam dokumen HTML, sekaligus bekerja di sisi server (server-side HTMLembedded scripting).

Tujuan dari bahasa scripting ini adalah untuk membuat aplikasi di mana aplikasi tersebut yang dibangun oleh PHP pada umumnya akan memberikan hasil pada web browser, tetapi prosesnya secara keseluruhan dijalankan di server [8]. 


\subsection{MySQL}

MySQL adalah sebuah basis data yang mengandung satu atau jumlah tabel. Tabel terdiri atas sejumlah baris dan setiap baris menggandung satu atau sejumlah tabel. Tabel terdiri atas sejumlah baris dan setiap baris mengandung satu atau sejumlah tabel. MySQL merupakan database server open source yang cukup popular keberadaannya. Dengan berbagai keunggulan yang dimiliki, membuat software database ini banyak digunakan oleh praktisi untuk membangun suatu project. Adanya fasilitas API (Application Programming Interface) yang dimiliki oleh Mysql, memungkinkan bermacam-macam aplikasi Komputer yang ditulis dengan berbagai bahasa pemograman dapat mengakses basis data MySQL.[9]

\subsection{Database}

Database (basis data) merupakan suatu kumpulan data terhubung yang disimpan secara bersama-sama pada suatu media, yang diorganisasi berdasarkan sebuah skema atau struktur tertentu dan dengan software untuk melakukan manipulasi untuk kegunaan tertentu. Database bisa diartikan juga sebagai sekumpulan data yang disusun dalam bentuk beberapa tabel yang saling memiliki relasi maupun berdiri sendiri.[10] [11]

\subsection{Entity Relationship Diagram (ERD)}

Entity Relational (ER) Modelling adalah sebuah pendekatan top-bottom dalam perancangan basis data yang dimulai dengan mengidentifikasikan data-data terpenting yang disebut dengan entitas dan hubungan antara entitas-entitas tersebut digambarkan dalam suatu model.[12]

\subsection{Penelitian Terkait}

Menurut Kurniawati [3] Melakukan analisa mengenai frekuensi keranjang belanja pada data penjualan. Latar belakang dari penelitian ini adalah persaingan yang ketat di dunia bisnis, khususnya pada industri swalayan, para pengembang mendiskusikan permasalahan tersebut dan menemukan solusinya, yaitu untuk meningkatkan penjualan swalayan salah satu cara mengatasinya adalah dengan tetap tersedianya berbagai jenis produk yang diminati atau dibutuhkan konsumen. Untuk mengetahui produk apa saja yang diminati oleh konsumen pengembang menggunakan
Algoritma Apriori dengan analisis asosisasi metode

Menurut Rezkiani[14] Melakukan penelitian mengenai analisa peminatan terhadap merk sepatu. Latar belakang masalah dari penelitian ini adalah meningkatnya persaingan antar penjual memaksa para pengembang untuk memikirkan strategi yang akan digunakan untuk mendongkrak kembali tingkat penjualan toko. Hasil dari penelitian ini adalah suatu pola pembelian yang diambil dari data transaksi penjualan, sehingga diketahui produk mana yang paling diminati oleh konsumen.

Menurut Afdal dan Rosadi [15] Melakukan penelitian kombinasi keterkaitan buku yang sering dipinjam untuk rekomendasi penataan buku pada perpustakaan. Latar belakang masalah dari penelitian ini adalah terjadinya kendala ketika kustomer yang akan meminjam buku akan kesulitan menemukan buku yang sering dipinjam, karena penataan buku pada perpustakaan tersebut belum sesuai dengan jenis buku dan masih belum memiliki skema yang pasti. Hasil dari penelitian ini adalah terciptanya aturan untuk mengetahui penataan buku sesuai dengan frekuensi buku yang sering dipinjam dan ditata sesuai dengan jenis bukunya.

Menurut Kurnawan, Marisa dan Purnomo[16] Melakukan penelitian tentang tingkat kelulusan mahasiswa. Latar belakang masalah dari penelitian ini merupakan hasil observasi pada Prodi Teknik Informatika Universitas Widyagama Malang, permasalahan yang terjadi yaitu tidak sedikit mahasiswa yang mengalami kendala dalam masa perkuliahan. Variabel yang diteliti ialah analisis asosisasi. Analisa pola frekuensi tinggi adalah salah satu tahap Analisis asosiasi yang banyak digunakan oleh para penliti untuk menghasilkan beberapa algoritma yang efisien. Hasil dari penelitian ini merupakan sistem yang dibuat untuk membantu mengetahui nilai matakuliah dan indeks prestasi kumulatif (IPK) yang digunakan untuk memprediksi kelulusan mahasiswa Teknik Informatika Universitas Widyagama Malang.

Menurut Fitrina, Kustanto dan Vulandari[17] yang melakukan penelitian tentang rekomendasi barang pada sebuah minimarket. Latar belakang permasalahan ini adalah kurangnya persediaan stok barang, yang menimbulkan kekecewaan pada 
konsumen dan juga stok barang sering tidak tepat sasaran sehingga stok barang yang dibeli tidak habis terjual dan akhirnya menyisakan stok barang lama yang tidak kunjung terjual. Hasil dari penelitian ini adalah terciptanya sebuah sistem rekomendasi barang untuk pembelian barang dengan menggunakan algoritma apriori, sehingga Minimarket Batox bisa meningkatkan penjualan dengan cara mengetahui minat konsumen.

\section{METODE PENELITIAN}

\subsection{Sumber Data}

1. Data Primer

Data primer disini adalah data Transaksi Penjualan yang ada di toko rokok elektrik berupa file Excel.

2. Data Sekunder

Data yang diperoleh dari catatan-catatan, laporan-laporan tertulis dan makalahmakalah, buku-buku bacaan ataupun dari internet yang ada kaitannya dengan masalah yang diteliti.

3. Studi pustaka

Pengumpulan data dengan jalan membaca buku referensi tentang Algoritma Apriori, atau majalah dan sumber data lainnya yang berhubungan dengan masalah yang diteliti seperti mencari referensi lewat perpustakaan kampus atau toko buku.

4. Browsing Internet

Pengumpulan data dengan menggunakan media internet seperti www.google.com dalam mencari artikel serta web yang mengulas tentang metode algoritma apriori sebagai rekomendasi stok barang.

\subsection{Metode Pengembangan Sistem}

Didalam metode pengembangan sistem terdapat perancangan sistem sebagai berikut

\section{a. Use Case Diagram}

Interaksi antara pengguna sistem (Admin) dengan program sistem alogritma apriori pada toko rokok elektrik.

\section{b. Class Diagram}

Memberi identitas pada sebuah kelompok data transaksi produk, yang disesuaikan atribut fungsinya untuk memberi karakteristik pada data transaksi yang dimiliki suatu objek di dalam ruang database.

\section{c. Activity Diagram}

Kegiatan diagram alur kerja yang menggambarkan perilaku sistem untuk aktivitas data transaksi dan data hasil rekomendasi barang.

\section{d. Sequence Diagram}

Subjek menjelaskan aspek dinamis dari sistem rekomendasi barang yang sedang dibangun berupa data transaksi dan hasil rekomendasi barang.

\section{e. Pengujian Sistem}

1. Pengujian BlackBox

Untuk dapat mengetahui apakah aplikasi dapat berjalan sesuai dengan fungsi yang telah dibuat.

2. Uji Kelayakan

Untuk mendapatkan penilaian langsung dari respon terhadap sistem yang dihasilkan. Pengujian akan dilakukan dengan menyebarkan angket kepada pemilik home industry dan masyarakat. Angket analisa kelayakan aplikasi diolah dengan menggunakan skala Likert dengan rentang skala 1 sampai 5 . Dengan presentase kelayakan aplikasi seperti yang dapat dilihat pada tabel 1.

\section{HASIL DAN PEMBAHASAN}

\subsection{Perhitungan Apriori}

\section{Pengumpulan Data Transaksi}

Data transaksi merupakan data penjualan produk yang ada di toko rokok elektrik yang telah dikelompokkan dari tanggal 3 sampai dengan tanggal 9 September 2019.

\section{Penentuan Kandidat Pertama}

Penentuan kandidat pertama dimulai dengan mencari pola frekuensi tinggi dari data transaksi tersebut, dalam tahap ini secara teknis adalah mencari kombinasi jenis barang yang memenuhi syarat minimum dari nilai support dalam database. Pada penelitian ini berdasarkan data transaksi ditentukan minimum support 10\%. Pola frekuensi dapat dilihat seperti pada Tabel 1.

\section{Tabel 1. Pola Frekuensi Tinggi}

\begin{tabular}{|l|l|c|}
\hline No. & Jenis Barang & Qty \\
\hline 1 & Exo Salt & 4 \\
\hline 2 & Clapton & 3 \\
\hline 3 & Basen & 5 \\
\hline 4 & Cartridge Stalker & 2 \\
\hline 5 & Mango Salt & 1 \\
\hline 6 & Creamfire & 2 \\
\hline 7 & Druga Foxy & 1 \\
\hline 8 & Cotton Bacon & 3 \\
\hline 9 & Cotton Key & 1 \\
\hline 10 & Kawat & 7 \\
\hline
\end{tabular}




\begin{tabular}{|c|l|c|}
\hline No. & Jenis Barang & Qty \\
\hline 11 & Recoil & 1 \\
\hline 12 & PW Salt & 2 \\
\hline 13 & PW Pods & 3 \\
\hline 14 & Cartridge Pandora & 1 \\
\hline 15 & Cartridge PW & 1 \\
\hline
\end{tabular}

Kandidat pertama diperoleh setelah menghitung nilai support dari setiap barang yang dijual. Nilai support kandidat pertama dapat dicari dengan rumus (1).

\section{Perhitungan Support Kandidat Pertama}

Support $(A)=\frac{\text { Jumlah Transaksi Mengandung A }}{\text { Total Transaksi }} \times 100 \%$

Support (Exo Salt) $=\frac{4}{18} \times 100 \%=22,22 \%$

Support $($ Clapton $)=\frac{3}{18} \times 100 \%=16,67 \%$

Support $($ Clapton $)=\frac{3}{18} \times 100 \%=16,67 \%$

Support $($ Basen $)=\frac{5}{18} \times 100 \%=27,78 \%$

Support (Cartridge Stalker) $=\frac{2}{18} \times 100 \%$

$$
=11,11 \%
$$

Support (Mango Salt) $=\frac{1}{18} \times 100 \%=5,56 \%$

Support $($ Creamfire $)=\frac{2}{18} x 100 \%=11,11 \%$

Support (Druga Foxy) $=\frac{1}{18} \times 100 \%=5,56 \%$

Support $($ Cotton Bacon $)=\frac{3}{18} \times 100 \%=16,67 \%$

Support (Cotton Key) $=\frac{1}{18} x 100 \%=5,56 \%$

Support $($ Kawat $)=\frac{7}{18} \times 100 \%=38,89 \%$

Support $($ Recoil $)=\frac{1}{18} x 100 \%=5,56 \%$

Support $(P W$ Salt $)=\frac{2}{18} \times 100 \%=11,11 \%$

Support $(P W$ Pods $)=\frac{3}{18} \times 100 \%=16,67 \%$

Support (Cartridge Pandora) $=\frac{1}{18} \times 100 \%$

$$
=5,56 \%
$$

Support $\left(\right.$ Cartridge PW) $=\frac{1}{18} x 100 \%=5,56 \%$

Support (Orange Poundcake) $=\frac{1}{18} \times 100 \%$

$$
=5,56 \%
$$

Support $($ Coffeelogy $)=\frac{1}{18} x 100 \%=5,56 \%$

Support $($ Amulet $)=\frac{1}{18} \times 100 \%=5,56 \%$

Support (Cartridge Amulet) $=\frac{2}{18} \times 100 \%$

$$
=11,11 \%
$$

Support $($ Kyoto Vanilla $)=\frac{1}{18} \times 100 \%=5,56 \%$

Support $($ Oreo Cheesecake $)=\frac{1}{18} x 100 \%=5,56 \%$

Support $($ Sumo $)=\frac{1}{18} \times 100 \%=5,56 \%$

Support $($ Bananalicious $)=\frac{1}{18} \times 100 \%=5,56 \%$

Support $($ Cotton Tees $)=\frac{2}{18} \times 100 \%=11,11 \%$

Support (Occ Artery) $=\frac{1}{18} \times 100 \%=5,56 \%$

Support (Charger AWT) $=\frac{1}{18} x 100 \%=5,56 \%$

Support (RDA Clone $)=\frac{1}{18} \times 100 \%=5,56 \%$

Support $($ Tokyonarila $)=\frac{1}{18} \times 100 \%=5,56 \%$

Support (Frutylicious) $=\frac{1}{18} \times 100 \%=5,56 \%$

Berikut hasil pencarian support sebagai penentuan kandidat pertama ditunjukkan pada Tabel 2.

Tabel 2. Calon Kandidat Pertama dan Nilai Support

\begin{tabular}{|l|c|r|}
\hline \multicolumn{1}{|c|}{ Item Set } & Qty & \multicolumn{1}{c|}{ Support } \\
\hline Exo Salt & 4 & $22,22 \%$ \\
\hline Clapton & 3 & $16,67 \%$ \\
\hline Basen & 5 & $27,78 \%$ \\
\hline Cartridge Stalker & 2 & $11,11 \%$ \\
\hline Mango Salt & 1 & $5,56 \%$ \\
\hline Creamfire & 2 & $11,11 \%$ \\
\hline Druga Foxy & 1 & $5,56 \%$ \\
\hline Cotton Bacon & 3 & $16,67 \%$ \\
\hline Cotton Key & 1 & $5,56 \%$ \\
\hline Kawat & 7 & $38,89 \%$ \\
\hline Recoil & 1 & $5,56 \%$ \\
\hline PW Salt & 2 & $11,11 \%$ \\
\hline PW Pods & 3 & $16,67 \%$ \\
\hline
\end{tabular}

Kandidat pertama adalah jenis barang yang memenuhi syarat minimum nilai support. Jika minimum nilai support pada penelitian ini adalah $10 \%$ maka data yang didapatkan seperti pada Tabel 3.

Tabel 3. Kandidat Pertama dan Nilai Support

\begin{tabular}{|l|c|c|}
\hline \multicolumn{1}{|c|}{ Item 1 } & Qty & Support \\
\hline Kawat & 7 & $38,89 \%$ \\
\hline Basen & 5 & $27,78 \%$ \\
\hline
\end{tabular}

\section{Penentuan Kandidat Kedua}

Kandidat kedua merupakan kombinasi dari item - item yang diambil dari kandidat pertama. Mencari kombinasi item sama seperti mencari relasi pada suatu himpunan matematika.

Langkah selanjutnya adalah mencari nilai support dari setiap kombinasi jenis barang 
yang ada pada tabel calon kandidat kedua. Berikut adalah perhitungan yang dilakukan untuk mencari nilai support calon kandidat kedua berdasarkan rumus (1).

\section{Perhitungan Support Kandidat Kedua Kombinasi}

Support Kandidat $2=\frac{\text { item Exo Salt, } \text { Clapton }}{\sum \text { transaksi }} \times 100 \%$

Exo Salt, Clapton $=\frac{\sum 2}{\sum 18} \times 100 \%=11,11 \%$

Exo Salt, Basen $=\frac{\sum 2}{\sum 18} \times 100 \%=11,11 \%$

Exo Salt, Kawat $=\frac{\sum 2}{\sum 18} \times 100 \%=11,11 \%$

Clapton, Kawat $=\frac{\sum 2}{\sum 18} \times 100 \%=11,11 \%$

Basen, Cartrige Stalker $=\frac{\sum 2}{\sum 18} \times 100 \%=11,11 \%$

Kawat, $P W$ Pods $=\frac{\sum 2}{\sum 18} \times 100 \%=11,11 \%$

Clapton, Basen $=\frac{\sum 1}{\sum 18} \times 100 \%=5,56 \%$

Clapton, Cartridge Stalker $=\frac{\sum 1}{\sum 18} \times 100 \%$

$$
=5,56 \%
$$

Clapton, Cotton Bacon $=\frac{\sum 1}{\sum 18} \times 100 \%=5,56 \%$

Clapton, $P W$ Salt $=\frac{\sum 1}{\sum 18} \times 100 \%=5,56 \%$

Basen, Creamfire $=\frac{\sum 1}{\sum 18} \times 100 \%=5,56 \%$

Basen, Cotton Bacon $=\frac{\sum 1}{\sum 18} \times 100 \%=5,56 \%$

Basen, Cartridge Amulet $=\frac{\sum 1}{\sum 18} \times 100 \%=5,56 \%$

Creamfire, Cotton Bacon $=\frac{\sum 1}{\sum 18} \times 100 \%=5,56 \%$

Creamfire, $P W$ Pods $=\frac{\sum 1}{\sum 18} \times 100 \%=5,56 \%$

Cotton Bacon, Kawat $=\frac{\sum 1}{\sum 18} \times 100 \%=5,56 \%$

Cotton Bacon, $P W$ Salt $=\frac{\sum 1}{\sum 18} \times 100 \%=5,56 \%$

Kawat, $P W$ Salt $=\frac{\sum 1}{\sum 18} \times 100 \%=5,56 \%$

$P W$ Salt, Cartridge Amulet $=\frac{\sum 1}{\sum 18} \times 100 \%$

$$
=5,56 \%
$$

Dari perhitungan di atas dapat disimpulkan seperti pada Tabel 4 .

Tabel 4. Calon Kandidat Kedua dan Nilai Support

\begin{tabular}{|l|l|c|c|}
\hline \multicolumn{1}{|c|}{ Item 1 } & \multicolumn{1}{c|}{ Item 2 } & Qty & Support \\
\hline Exo Salt & Clapton & 2 & $11,11 \%$ \\
\hline Exo Salt & Basen & 2 & $11,11 \%$ \\
\hline Exo Salt & Kawat & 2 & $11,11 \%$ \\
\hline Clapton & Kawat & 2 & $11,11 \%$ \\
\hline Basen & Cartridge Stalker & 2 & $11,11 \%$ \\
\hline Kawat & PW Pods & 2 & $11,11 \%$ \\
\hline Exo Salt & Cartridge Stalker & 1 & $5,56 \%$ \\
\hline Clapton & Basen & 1 & $5,56 \%$ \\
\hline Clapton & Cartridge Stalker & 1 & $5,56 \%$ \\
\hline Clapton & Cotton Bacon & 1 & $5,56 \%$ \\
\hline Clapton & PW Salt & 1 & $5,56 \%$ \\
\hline Basen & Creamfire & 1 & $5,56 \%$ \\
\hline Basen & Cotton Bacon & 1 & $5,56 \%$ \\
\hline Basen & Cartridge Amulet & 1 & $5,56 \%$ \\
\hline Creamfire & Cotton Bacon & 1 & $5,56 \%$ \\
\hline Creamfire & PW Pods & 1 & $5,56 \%$ \\
\hline Cotton Bacon & Kawat & 1 & $5,56 \%$ \\
\hline Cotton Bacon & PW Salt & 1 & $5,56 \%$ \\
\hline Kawat & PW Salt & 1 & $5,56 \%$ \\
\hline PW Salt & Cartridge Amulet & 1 & $5,56 \%$ \\
\hline
\end{tabular}

Dari pencarian perhitungan kandidat kedua, maka ditentukan kandidat kedua pada Tabel 5.

\section{Tabel 5. Kandidat Kedua dan Nilai Support}

\begin{tabular}{|l|l|c|r|}
\hline \multicolumn{1}{|c|}{ Item 1 } & \multicolumn{1}{|c|}{ Item 2 } & Qty & \multicolumn{1}{c|}{ Support } \\
\hline Exo Salt & Clapton & 2 & $11,11 \%$ \\
\hline Exo Salt & Basen & 2 & $11,11 \%$ \\
\hline Exo Salt & Kawat & 2 & $11,11 \%$ \\
\hline Clapton & Kawat & 2 & $11,11 \%$ \\
\hline Basen & $\begin{array}{l}\text { Cartridge } \\
\text { Stalker }\end{array}$ & 2 & $11,11 \%$ \\
\hline Kawat & PW Pods & 2 & $11,11 \%$ \\
\hline
\end{tabular}

\section{Pencarian Kandidat Ketiga}

Pencarian kandidat ketiga merupakan kombinasi dari item - item yang memenuhi nilai support dari kandidat kedua. Iterasi terus dilakukan hingga mencapai kesimpulan maksimum. Pada pencarian kandidat ketiga dengan menggunakan Tabel 5. yang memiliki item 1 yang sama dengan rumus(1).

\section{Perhitungan Support Kandidat Ketiga Kombinasi}

Support kombinasi jenis barang

Exo Salt, Clapton, Basen

$=\frac{\text { Eitem Exo Salt, Clapton, Basen }}{\sum \text { transaksi }} \times 100 \%$

Exo Salt, Clapton, Basen $=\frac{\sum 1}{\sum 18} \times 100 \%=5,56 \%$

Exo Salt, Clapton, Kawat $=\frac{\sum 1}{\sum 18} \times 100 \%=5,56 \%$

Exo Salt, Basen, Cartridge Stalker $=\frac{\sum 1}{\sum 18} x 100 \%$

$$
=5,56 \%
$$


Exo Salt, Clapton, Cartridge Stalker $=\frac{\sum 1}{\sum 18} x 100 \%$

$$
=5,56 \%
$$

Basen, Clapton, Cartridge Stalker $=\frac{\sum 1}{\sum 18} \times 100 \%$

$$
=5,56 \%
$$

Dari perhitungan support kandidat ketiga kombinasi dapat disimpulkan pada Tabel 6.

Tabel 6. Kandidat Ketiga dan Nilai Support

\begin{tabular}{|c|l|l|c|c|}
\hline Item 1 & Item 2 & Item 3 & Qty & Support \\
\hline Exo Salt & Clapton & Basen & 1 & 5,56 \\
\hline Exo Salt & Clapton & Kawat & 1 & 5,56 \\
\hline Exo Salt & Basen & $\begin{array}{l}\text { Cartridge } \\
\text { Stalker }\end{array}$ & 1 & 5,56 \\
\hline
\end{tabular}

Dari Tabel 6 terlihat kandidat ketiga tersebut tidak satupun memenuhi minimum support yang sudah ditentukan yaitu $10 \%$, maka iterasi berhenti pada kombinasi 3itemset.

\section{Pembentukan Aturan Asosiasi}

Iterasi pada pencarian pola frekuensi tinggi berhenti pada kombinasi 3-itemset karena sudah tidak ada lagi yang dapat dikombinasikan dan tidak memenuhi minimal support yang sudah ditentukan yaitu 10\%. Proses pencarian kandidat berhenti pada kandidat ketiga.

Berdasarkan Tabel 6. suatu keterkaitan barang dapat dibentuk terlebih dahulu seperti pada Tabel 7.

Tabel 7. Keterkaitan Jenis Barang

\begin{tabular}{|l|}
\hline Keterkaitan Jenis Barang \\
\hline Exo Salt $=>$ Clapton \\
\hline Exo Salt $=>$ Basen \\
\hline Exo Salt $=>$ Kawat \\
\hline Clapton $=>$ Kawat \\
\hline Basen $=>$ Cartridge Stalker \\
\hline Kawat $=>$ PW Pods \\
\hline
\end{tabular}

Keterkaitan jenis barang tersebut dibentuk berdasarkan tabel kandidat kedua dan ketiga. Keterkaitan jenis barang di atas dapat diartikan jika membeli " $x$ " maka akan membeli "y" contohnya sebagai berikut : "Jika membeli produk Exo Salt maka akan membeli Produk Clapton". Dengan nilai support $11,11 \%$ maka dapat dikatakan bahwa pelanggan yang membeli produk "Exo Salt" kemungkinan $11,11 \%$ juga membeli produk "Clapton".

Suatu aturan asosiasi dapat ditentukan berdasarkan dua parameter yaitu nilai support dan nilai confidence. Setelah nilai support sudah didapatkan, maka selanjutnya adalah mencari nilai confidence.

Nilai confidence merupakan presentase kuatnya keterkaitan suatu barang dengan barang yang lain. Inilah penentu apakah barang tersebut direkomendasikan untuk di stok ulang atau tidak, semakin tinggi nilai confidence semakin tinggi nilai rekomendasi barang, semakin rendah nilai confidence maka berpengaruh nilai rekomendasi untuk tidak direkomendasikan kepembeli karena hanya sedikit pelanggan yang membelinya. Minimal nilai confidence yang ditetapkan adalah $50 \%$ karena dianggap cukup mewakili dari keseluruhan transaksi.

\section{Menentukan Confidence}

Ketika semua pola frekuensi telah ditemukan, barulah dicari keterkaitan jenis barang yang memenuhi syarat minimum nilai confidence dengan menghitung nilai confidence setiap aturan asosiasi. Berikut hitungan manual mencari nilai confidence yang dicari berdasarkan rumus (2):

$$
\begin{aligned}
\text { confidence }=P(B \mid A) & \\
& =\frac{\sum \text { Transaksi mengandun A dan } B}{\sum \text { Transaksi mengandung } A} \\
& \times 100 \%
\end{aligned}
$$

Cartridge Stalker, Basen $=\frac{\sum 2}{\sum 2} \times 100 \%=100 \%$

Clapton, Kawat $=\frac{\sum 2}{\sum 3} \times 100 \%=66,67 \%$

Clapton, Exo Salt $=\frac{\sum 2}{\sum 3} \times 100 \%=66,67 \%$

PW Pods, Kawat $=\frac{\sum 2}{\sum 3} \times 100 \%=66,67 \%$

Exo Salt, Kawat $=\frac{\sum 2}{\sum 4} \times 100 \%=50 \%$

Exo Salt, Basen $=\frac{\sum 2}{\sum 4} \times 100 \%=50 \%$

Exo Salt, Clapton $=\frac{\sum 2}{\sum 4} \times 100 \%=50 \%$

Basen, Cartridge Stalker $=\frac{\sum 2}{\sum 5} \times 100 \%=40 \%$

Basen, Exo Salt $=\frac{\sum 2}{\sum 5} \times 100 \%=40 \%$

Kawat, $P W$ Pods $=\frac{\sum 2}{\sum 6} \times 100 \%=28,57 \%$

Kawat, Clapton $=\frac{\sum 2}{\sum 6} \times 100 \%=28,57 \%$

Kawat, Exo Salt $=\frac{\sum 2}{\sum 6} \times 100 \%=28,57 \%$

Hasil perhitungan di atas dapat ditunjukkan pada Tabel 8.

Tabel 8. Confidence Aturan Asosiasi

\begin{tabular}{|l|c|r|}
\hline Aturan Asosiasi & Qty & Confidence \\
\hline Cartridge Stalker $=>$ Basen & 2 & $100,00 \%$ \\
\hline
\end{tabular}




\begin{tabular}{|l|c|r|}
\hline Aturan Asosiasi & Qty & Confidence \\
\hline Clapton => Kawat & 2 & $66,67 \%$ \\
\hline Clapton => Exo Salt & 2 & $66,67 \%$ \\
\hline PW Pods => Kawat & 2 & $66,67 \%$ \\
\hline Exo Salt => Kawat & 2 & $50,00 \%$ \\
\hline Exo Salt => Basen & 2 & $50,00 \%$ \\
\hline Exo Salt => Clapton & 2 & $50,00 \%$ \\
\hline Basen => Cartridge Stalker & 2 & $40,00 \%$ \\
\hline Basen => Exo Salt & 2 & $40,00 \%$ \\
\hline Kawat => PW Pods & 2 & $28,57 \%$ \\
\hline Kawat => Clapton & 2 & $28,57 \%$ \\
\hline Kawat => Exo Salt & 2 & $28,57 \%$ \\
\hline
\end{tabular}

Dari Tabel 8. dapat diketahu bahwa minimum confidence yang telah ditentukan $50 \%$ maka terdapat 7 aturan asosiasi yang memenuhi minimal confidence.

\section{Aturan Asosiasi Final}

Dari Tabel 8. dapat diketahui aturan asosiasi yang terbentuk adalah seperti pada Tabel 9.

Tabel 9. Hasil Aturan Asosiasi

\begin{tabular}{|c|c|c|c|}
\hline No & Aturan & Confidence & (\%) \\
\hline & Jika dibeli Cartridge & & \\
\hline 1 & $\begin{array}{l}\text { Stalker, maka akan } \\
\text { dibeli Basen }\end{array}$ & $2 / 2$ & $100 \%$ \\
\hline 2 & $\begin{array}{l}\text { Jika dibeli Clapton, } \\
\text { maka akan dibeli } \\
\text { Kawat }\end{array}$ & $2 / 3$ & $66,67 \%$ \\
\hline 3 & $\begin{array}{l}\text { Jika dibeli Clapton, } \\
\text { maka akan dibeli } \\
\text { Exo Salt }\end{array}$ & $2 / 3$ & $66,67 \%$ \\
\hline 4 & $\begin{array}{l}\text { Jika dibeli PW Pods, } \\
\text { maka akan dibeli } \\
\text { Kawat }\end{array}$ & $2 / 4$ & $66,67 \%$ \\
\hline 5 & $\begin{array}{l}\text { Jika dibeli Exo Salt, } \\
\text { maka akan dibeli } \\
\text { Kawat }\end{array}$ & $2 / 4$ & $50,00 \%$ \\
\hline 6 & $\begin{array}{l}\text { Jika dibeli Exo Salt, } \\
\text { maka akan dibeli } \\
\text { Basen }\end{array}$ & $2 / 4$ & $50,00 \%$ \\
\hline 7 & $\begin{array}{l}\text { Jika dibeli Exo Salt, } \\
\text { maka akan dibeli } \\
\text { Clapton }\end{array}$ & $2 / 4$ & $50,00 \%$ \\
\hline
\end{tabular}

Jenis dan Kategori barang yang direkomendasikan seperti pada Tabel 10.

Tabel 10. Hasil Rekomendasi Barang

\begin{tabular}{|c|l|c|}
\hline No & \multicolumn{1}{|c|}{ Jenis Barang } & Kategori Barang \\
\hline 1. & Basen & Device \& Tools \\
\hline 2. & Cartridge Stalker & Device \& Tools \\
\hline 3. & Clapton & Device \& Tools \\
\hline 4. & Exo Salt & Liquid \\
\hline 5. & Kawat & Device \& Tools \\
\hline 6. & PW Pods & Device \& Tools \\
\hline
\end{tabular}

\subsection{Perancangan Sistem}

Pada tahap ini pembentukan dan perancangan sistem dilakukan sehingga nantinya dapat tercipta suatu sistem yang baik.

\subsubsection{Use Case Diagram}

Use case diagram mempresentasikan sebuah interaksi antar aktor dengan sistem, berikut ini adalah use case diagram sistem rekomendasi barang dengan algoritma apriori.

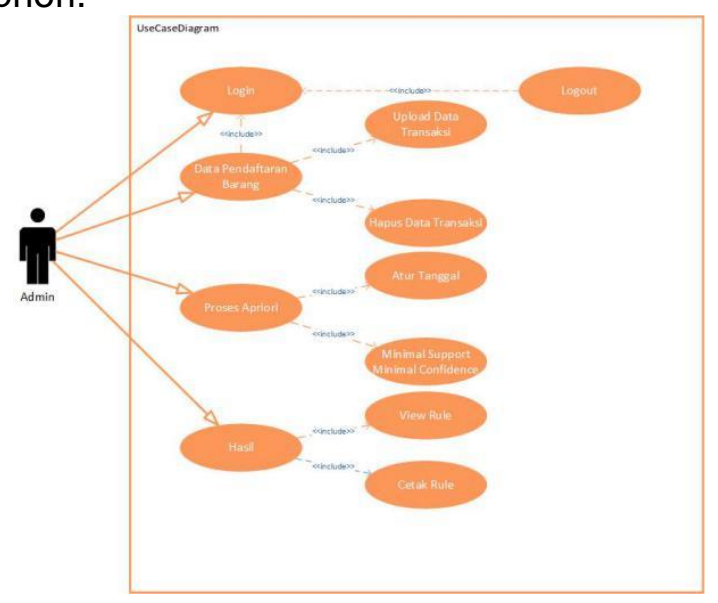

Gambar 1. Use Case Diagram

\subsection{Implementasi Sistem}

Dalam bahasan ini akan diterangkan dan dijelaskan tentang urutan penggunaan program. Hardware dan software yang dapat mendukung program ini adalah PC minimal menggunakan spesifikasi processor Intel P IV $2.66 \mathrm{GHz}$, RAM $1 \mathrm{~GB}$, dan HDD $160 \mathrm{~GB}$. Software yang digunakan Windows 7, Xampp, MySQL.

\subsubsection{Proses Perhitungan}

Gambar 2 adalah tampilan proses perhitungan. Untuk menjalankan proses perhitungan klik tombol "Proses" setelah memasukan Start Date, End Date, Minimal Support, Minimal Confidence pada menu Proses Apriori.

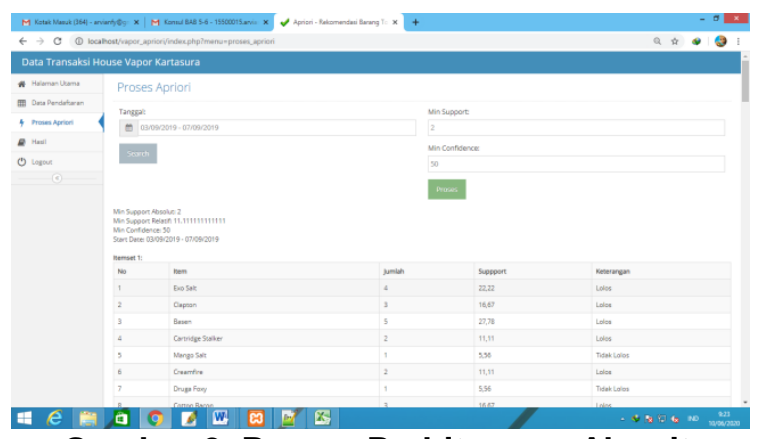

Gambar 2. Proses Perhitungan Algoritma Apriori 2 Kombinasi

\subsubsection{Hasil Dan Cetak Laporan}

Pada menu hasil bisa melihat riwayat proses yang sudah dilakukan sebelumnya 
dan juga bisa melakukan cetak hasil seperti pada Gambar 3.

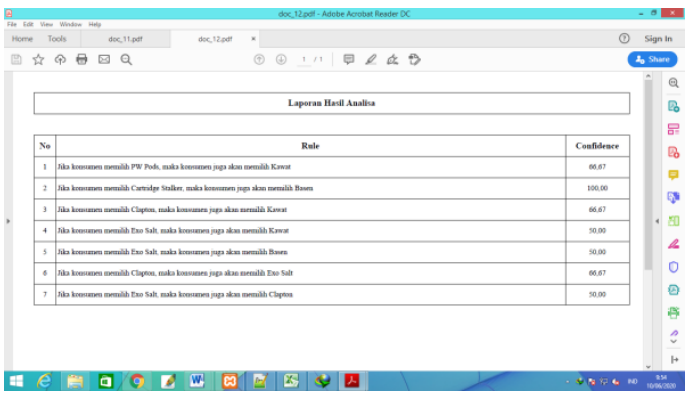

Gambar 3. Hasil Cetak Laporan Proses Apriori 2 Kombinasi

\subsection{Pengujian Sistem}

Pengujian sistem akan dilaksanakan dengan cara pengujian fungsionalitas sistem. Pengujian fungsionalitas sistem dilakukan dengan teknik pengujian black box testing dan uji validitas. Berikut merupakan tabel pengujian BalckBox dari perhitungan apriori.

\section{Tabel 11. Uji BlackBox Rule}

\begin{tabular}{|c|c|c|c|}
\hline Test Case & $\begin{array}{c}\text { Hasil } \\
\text { Harapan }\end{array}$ & $\begin{array}{c}\text { Hasil } \\
\text { Keluaran }\end{array}$ & $\begin{array}{c}\text { Hasil } \\
\text { Uji }\end{array}$ \\
\hline $\begin{array}{l}\text { Input minimal } \\
\text { confidence dan } \\
\text { minimal } \\
\text { support } \\
\text { dengan nilai } 0 \text { - } \\
100\end{array}$ & $\begin{array}{l}\text { Cek besaran } \\
\text { nilai dan } \\
\text { tersimpan di } \\
\text { tabel rule } \\
\text { database } \\
\text { apriori }\end{array}$ & $\begin{array}{l}\text { Data rule } \\
\text { tersimpan di } \\
\text { tabel rule } \\
\text { database } \\
\text { apriori }\end{array}$ & Seusai \\
\hline $\begin{array}{l}\text { Input minimal } \\
\text { confidence dan } \\
\text { minimal } \\
\text { support } \\
\text { dengan nilai } \\
\text { Kosong atau } \\
\text { tidak isi }\end{array}$ & $\begin{array}{l}\text { Penolakan } \\
\text { dan muncul } \\
\text { internal error }\end{array}$ & $\begin{array}{l}\text { Muncul } \\
\text { tampilan } \\
\text { internale } \\
\text { error }\end{array}$ & Sesuai \\
\hline
\end{tabular}

Tabel 12. Uji Validitas

\begin{tabular}{|c|c|c|c|}
\hline Data & $\begin{array}{l}\text { Event yang sedang } \\
\text { berlangsung }\end{array}$ & $\begin{array}{c}\text { Sistem } \\
\text { (Algoritm } \\
\text { a Apriori) }\end{array}$ & $\begin{array}{c}\text { Perbedaan } \\
\text { yang } \\
\text { terjadi }\end{array}$ \\
\hline $\begin{array}{l}\text { Data } \\
\text { Testing }\end{array}$ & $\begin{array}{l}\text { Kawat } \\
\text { Basen } \\
\text { Exo Salt } \\
\text { Clapton } \\
\text { Cotton Bacon } \\
\text { PW Pods } \\
\text { Cartidge Stalker } \\
\text { Creamfire } \\
\text { PW Salt } \\
\text { Cartidge Amulet } \\
\text { Cotton Tees } \\
\text { Druga Foxy } \\
\text { Cotton Key } \\
\text { Recoil } \\
\text { Cartidge Pandora } \\
\text { Cartdige PW } \\
\text { Orange Poundcake } \\
\text { Coffeelogy } \\
\text { Amulet } \\
\text { Kyoto Vanilla }\end{array}$ & $\begin{array}{l}\text { Kawat } \\
\text { Basen } \\
\text { Exo Salt } \\
\text { Clapton } \\
\text { Cotton } \\
\text { Bacon } \\
\text { PW Pods } \\
\text { Cartidge } \\
\text { Stalker } \\
\text { Creamfire } \\
\text { PW Salt } \\
\text { Cartridge } \\
\text { Amulet } \\
\text { Cotton } \\
\text { Tees }\end{array}$ & $\begin{array}{l}1 \text { item yang } \\
\text { perlu } \\
\text { ditambahka } \\
\mathrm{n} \text { dalam } \\
\text { rekomendas } \\
\text { i yaitu } \\
\text { Mango Salt }\end{array}$ \\
\hline $\begin{array}{l}\text { Data } \\
\text { Training }\end{array}$ & $\begin{array}{l}\text { Kawat } \\
\text { Basen } \\
\text { Exo Salt } \\
\text { Clapton }\end{array}$ & $\begin{array}{l}\text { Kawat } \\
\text { Basen } \\
\text { Exo Salt } \\
\text { Clapton }\end{array}$ & $\begin{array}{l}\text { Tidak ada } \\
\text { lagi } \\
\text { rekomendas } \\
\text { i item yang }\end{array}$ \\
\hline
\end{tabular}

\begin{tabular}{|c|l|l|l|}
\hline Data & $\begin{array}{l}\text { Event yang sedang } \\
\text { berlangsung }\end{array}$ & $\begin{array}{l}\text { Sistem } \\
\text { (Algoritm } \\
\text { a Apriori) }\end{array}$ & $\begin{array}{c}\text { Perbedaan } \\
\text { yang } \\
\text { terjadi }\end{array}$ \\
\hline \multirow{6}{*}{ Cotton Bacon } & Cotton & belum \\
& $\begin{array}{l}\text { PW Pods } \\
\text { Cartidge Stalker }\end{array}$ & $\begin{array}{l}\text { Bacon } \\
\text { PW Pods }\end{array}$ & \\
Creamfire & Cartidge & \\
& PW Salt & Stalker & \\
& Cartidge Amulet & Creamfire & \\
Cotton Tees & PW Salt & \\
Druga Foxy & Cartridge & \\
Cotton Key & Amulet & \\
& Recoil & Cotton & \\
Cartidge Pandora & Tees & \\
Cartdige PW & Mango & \\
Orange & Salt & \\
\hline
\end{tabular}

Dari hasil pengujian terdapat perbedaan kuantitas. Pada event yang berlangsung kuantitas lebih banyak dari rekomendasi item pada sistem disebabkan karena adanya perbedaan sudut pandang dalam penentuan. Pada event yang berlangsung berdasarkan jumlah pembelian barang selanjutnya.

Sedangkan pada penelitian ini sudut pandang didasarkan pada pola pembelian konsumen sehingga didapatkan prediksi barang yang saling terkait dalam keranjang barang konsumen.

Dari hal tersebut maka sistem dapat menjadi sebuah referensi dalam merekomendasikan barang untuk melengkapi pembelian stok pada event yang berlangsung.

\subsection{Penerapan Pada Etalase Toko}

Dari hasil aturan asosiasi pada Tabel 10. Bisa kita dapatkan aturan yang akan kita terapkan pada penyusunan barang pada etalase toko, seperti pada Gambar 4.

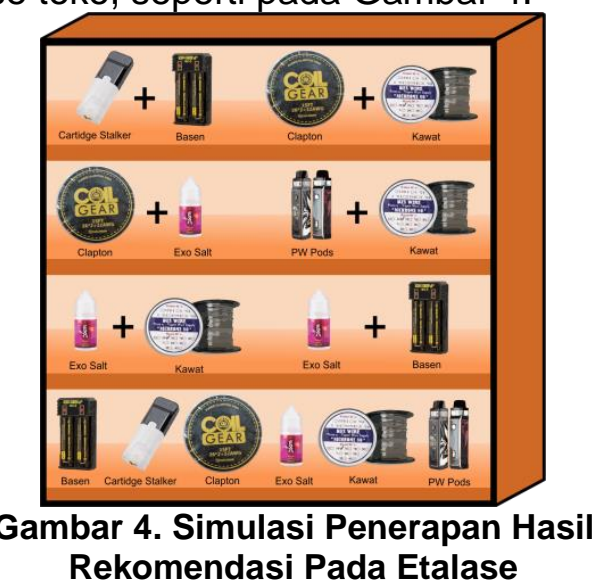

\section{PENUTUP}

5.1. Kesimpulan

Berdasarkan tujuan penelitian dapat disimpulkan bahwa penerapan algoritma apriori pada sistem rekomendasi barang di toko rokok elektrik : 
1. Terciptanya sebuah sistem rekomendasi barang untuk pembelian barang dengan menggunakan algoritma apriori.

2. Dari pengujian tersebut dapat disimpulkan bahwa algoritma yang digunakan program sesuai dengan perhitungan algoritma apriori.

3. Sesuai dengan hasil diaplikasi pada Studi Kasus 1 ditemukan bahwa terdapat 7 aturan asosiasi dimana semua aturan tersebut adalah asosiasi itemset 2 dengan minimal support $10 \%$ dan minimal confidence $50 \%$.

4. Sesuai dengan pada hasil diaplikasi pada Studi Kasus 2 ditemukan bahwa terdapat 150 aturan asosisasi dimana 109 aturan asosiasi adalah itemset 3 dan 41 aturan asosiasi adalah itemset 2 dengan minimal support $5 \%$ dan minimal confidence $100 \%$.

5. Dengan perbandingan Studi Kasus 1 dan Studi Kasus 2 tersebut, didapatkan hasil yang lebih efisien terdapat pada Studi Kasus 1 dengan hasil 7 aturan asosiasi dengan minimal support $10 \%$ dan minimal confidence $50 \%$. Rata - rata confidence dari 7 aturan asosiasi adalah 64\%.

\subsection{Saran}

Sistem rekomendasi barang dengan algoritma apriori ini memiliki kelemahan diantara sistem tidak terintegerasi dengan sistem yang telah berjalan di Toko Rokok Elektrik. Algoritma apriori memiliki kelemahan yaitu melakukan scan data yang berulangulang sehingga memori yang terpakai cukup banyak. Penelitian ini dapat dikembangkan pada metode aturan asosiasi lainya, seperti FP-Growth dan Hash Based. Keduanya merupakan pengembangan dari algortima apriori.

Pada gambar simulasi penerapan hasil apriori rekomendasi pada etalase toko, bisa digunakan sebagai acuan untuk penataan produk pada etalase toko rokok elektrik sehingga harapannya bisa meningkatkan penjualan dan ketertarikan konsumen terhadap produk yang dijual.

\section{DAFTAR PUSTAKA}

[1] P. H. Simbolon, "Implementasi Data Mining Pada Sistem Persediaan Barang Menggunakan Algoritma Apriori ( Studi Kasus: Srikandi Cash Credit Elektronic dan Furniture )," vol. 6, no. 4, pp. 401406, 2019.

[2] A. -, F. Marisa, and D. Purnomo,
"Penerapan Algoritma Apriori Terhadap Data Penjualan di Toko Gudang BM," JOINTECS (Journal Inf. Technol. Comput. Sci., vol. 1, no. 1, pp. 1-5, 2016. [3] L. Kurniawati, A. E. Kusuma, and B. Dewansyah, "Implementasi Algoritma Apriori Untuk Menentukan Persediaan Spare Part Compressor," Comput. Eng. Sci. Syst. J., vol. 4, no. 1, p. 6, 2019.

[4] R. Vulandari, "Data Mining: Teori dan Aplikasi Rapidminer. Surakarta," Data Min. Teor. dan Apl. Rapidminer. Surakarta, 2017.

[5] Kusrini and E. T. Luthfi, Algoritma Data Minning, 1st ed. Yogyakarta: ANDI, 2009.

[6] H. Dewantara, P. B. Santosa, and N. W. Setyanto, "Perancangan Aplikasi Data Mining Dengan Algoritma Apriori Untuk Frekuensi Analisis Keranjang Belanja Pada Data Transaksi Penjualan," Tek. Ind., pp. 415-426, 2013.

[7] A. Solichin S.Kom, "Pemrograman Web dengan PHP dan MySQL - Achmad Solichin - Google Buku," Univ. Budi Luhur, no. January, p. 215, 2016.

[8] N. M. I. M. M. I Dewa Gede Wahya Dhiyatmika, I Ketut Gede Darma Putra, "Aplikasi Augmented Reality Magic Book Pengenalan Binatang untuk Siswa TK," Lontar Komput., vol. 6, no. 2, pp. 589596, 2015.

[9] R. Yanto, Manajemen Basis Data Menggunakan MySQL. 2016.

[10] Canggih Ajika Pamungkas, Pengantar dan Implementasi Basis Data. 2017.

[11] S. Indrajani, Sistem Informasi. Jakarta: PT Elex Media Komputindo, 2011.

[12] S. Indrajani, "MM. Database Design," vol. 42, 2015.

[13] J. H. Mustakini, Analisis \& Desain, Ed keIII. Andi Offset, 2005.

[14] Rezkiani, "Implementasi Data Minning dengan Algoritma Apriori," 2016.

[15] M. Afdal and M. Rosadi, "Penerapan Association Rule Mining Untuk Analisis," vol. 5, no. 1, pp. 99-108, 2019.

[16] I. Kurnawan, F. Marisa, and P. Purnomo, "Implementasi Data Mining Dengan Algoritma Apriori Untuk Memprediksi Tingkat Kelulusan Mahasiswa," J. Teknol. dan Manaj. Inform., vol. 4, no. 1, 2018.

[17] N. Fitrina, Kustanto, and R. T. Vulandari, "Penerapan Algoritma Apriori Pada Sistem Rekomendasi Barang Di Minimarket Batox," J. Teknol. Inf. dan 
Komun., vol. 6, no. 2, pp. 21-27, 2018. 